\title{
Türkiye'de Yükseköğretimde İnsan Hakları Eğitimi: Kamu Yönetimi Bölümleri Örneği
}

\section{Human Rights Education in Higher Education in Turkey: Department of Public \\ Administration As An Example}

\section{Duru Şahyar Akdemir ${ }^{1}$}

Başvuru Tarihi: 09.10.2018

Kabul Tarihi: 21.08.2019

Öz

Insan hakları "insanlı̆̆ın ortak dili" olarak tanımlanmaktadır. Bu bakımdan insan hakları eğitimi de bu dili öğrenmek olarak anlaşılabilir. Insan haklarını hem kendimizde hem de başkalarında korumak için herkesin insan hakları eğitimi alması gerekmektedir. Ancak insan haklarının korunması bakımından bazı meslekler özellikle önemlidir. Bu mesleklerin önemli bir kısmı da kamu yönetimi alanında yer alan mesleklerdir.

Çalışmanın amacı 2018-2019 eğitim yılında yükseköğretim kurumlarında adında "kamu yönetimi" ifadesi bulunan lisans programlarında insan hakları konusunun bir ders olarak yer alıp almadiğını ve ne şekilde yer aldığını belirlemektir. Çalışmada nicel araştırma yöntemi çerçevesinde betimsel metot kullanılarak ilgili bölümlerin öğretim programları incelenmiş ve bu konuda değerlendirmelerde bulunulmuştur. Elde edilen bulgular Türkiye'de yükseköğretim kurumlarında adında "kamu yönetimi" ifadesi yer alan bölümlerinde insan hakları konusuna ilişkin yeterli dersin olmadiğını ortaya koymuştur.

Anahtar Kelimeler: Kamu Yönetimi, İnsan Hakları, İnsan Hakları Eğitimi, Kamu Yönetimi Ĕ̈itimi, Yükseköğretim

\begin{abstract}
Human rights are defined as "the common language of humanity". In this respect, human rights education can be understood as learning this language. In order to protect human rights both in ourselves and in others, everyone needs human rights education. However, some professions are particularly important for the protection of human rights. An important part of these professions are occupations in the field of public administration.
\end{abstract}

\footnotetext{
1 Anadolu Üniversitesi İktisat Fakültesi, dsakdemir@anadolu.edu.tr, ORCID: 000-0003-2374-9770
} 
The aim of this study is to determine whether there is a human rights course (or human rights related course) in public administration departments of higher education institutions in 20182019 academic year.

In the study, descriptive method was used within the framework of quantitative research method. In this context, the curriculas were examined and evaluations were made. The findings revealed that there is not enough courses on human rights in public administration departments of higher education institutions in Turkey.

Keywords: Public Administration, Human Rights, Human Rights Education, Public Administration Education, Higher Education

\section{Giriş}

İnsan hakları "insan" olduğumuz için sahip olduğumuz haklardır. Kişiler sadece insan oldukları için birbirlerine "insan haklarına uygun" şekilde davranmalıdır. Ancak "insan haklarına uygun" şekilde davranmak için kişilerin insan haklarına ilişkin doğru bilgiye sahip olmaları gerekmektedir. İnsan haklarına ilişkin doğru bilgiye ise ancak insan hakları eğitimi ile ulaşllabilir (Kuçuradi, 2004a, s.67-68).

Flowers vd. (2000, s.15) etkili bir insan hakları eğitiminin "değerler ve tutumlarda değişikliklere" neden olduğunu kişileri güçlendirdiğini, "dayanışmayı" ve "katılımcı eğitimi" teşvik ettiğini belirtmektedir. Bu çerçeveden bakıldığında insan hakları eğitimi herkes için gerekli bir eğitimdir. Ancak bu eğitimin bazı gruplar için diğerlerine kıyasla daha önemli olduğu belirtilmektedir. Bu gruplar şöyledir: "Küçük çocuklar ve ebeveynleri; her tür eğitimci, öğretmen ve müdürler; doktorlar, hemşireler, avukatlar, hâkimler, sosyal çalışmacilar, gazeteciler, polisler ve askeri yetkililer; korunmaya muhtaç kimseler; insan hakları savunucuları ve kâr amacı gütmeyen örgütler; seçilmiş ya da atanmış kamu çalışanları, toprak sahipleri, işadamları, dini liderler gibi kararları ve politikaları etkileyebilen güçlü kimseler" (Flowers vd., 2000, s.18-19). Aynı konuda Kuçuradi (2004a, s.264), "insan haklarıyla ilgili olmayan meslek" olmadığını ancak, bazı mesleklerin "insan haklarının korunmasıyla doğrudan" ilişkisi olduğunu belirtmektedir. Kuçuradi (2004a, s.265), özellikle "kamu görevlileri, yöneticiler, yargıçlar, savcılar, siyasetçiler, polisler, askerler" ve "doğa bilimcilerin" insan hakları konusunda eğitim almaları gerektiğinin altını çizmiştir.

Diğer taraftan kamu görevlisi; bir kamu kurumunda çalışan kişi olarak tanımlanabilir. Eryılmaz (2016, s.328-329) geniş anlamda kamu görevlilerini "kamu kesiminde görev yapan ve farklı hukuki statülere sahip tüm personel" olarak tanımlamıştır. Bu çerçevede kamu personeli deyince askerden, polise, öğretmenden, müdüre, devlet hastanelerinde çalş̧an doktordan devlet dairelerinde çalışan memura kadar oldukça geniş bir çalışan grubundan söz etmemiz gerekmektedir. Söz konusu çalışan grubu içindeki kişilerin birbirinden farklı eğitimlere sahip oldukları bilinmektedir. 
Kamuda çalışan herkes kamu yönetimi lisans derecesine sahip değildir. Ancak kamu yönetimi alanından mezun olan birçok kimse "ekonomik koşullar, iş güvencesi, devlete hizmet etme" gibi sebeplerden dolayı kamuda çalışmayı istemekte ve kamu yönetimi/siyaset bilimi ve kamu yönetimi vb. bölümlerde lisans eğitimini tamamlamaktadır (Çiner, 2015, s.3). Bu varsayımdan hareketle insan hakları düşüncesi, insan hakları eğitimi ve kamu yönetimi bölümlerini bir araya getirdiğimizde ilgili lisans programları için insan hakları eğitimi oldukça önemli bir eğitim, araştırma ve çalışma alanı olarak görünmektedir. Literatürde insan hakları eğitiminin ilköğretim, orta öğretim ve polis eğitimindeki yeri ve önemi gibi konularda yapılmış önemli akademik çalışmalar ve lisansüstü tezler mevcuttur. Ancak kamu yönetimi eğitimi ve insan hakları konuları üzerinde yapılan araştırmalar oldukça kısıtlıdır. Çalışmanın bu bakımdan insan hakları ve kamu yönetimi alanlarında önemli bir eksiği gidereceği düşünülmektedir.

Bu bakışla çalışmada öncelikle insan hakları eğitimine değinilecektir. İnsan hakları eğitiminin kapsamı ve gelişimi ele alınacaktır. Ardından Türkiye'de insan hakları eğitimi incelenecektir. Sonrasında Türkiye'de yükseköğretimde kamu yönetimi eğitiminin gelişiminden söz edilecektir. Son olarak ise mevcut kamu yönetimi öğretim programlarında insan hakları dersine ilişkin yapılan analiz sonuçlarına yer verilecektir.

\section{Insan Hakları Eğitimi}

\section{İnsan Hakları Eğitiminin Kapsamı}

İnsan hakları eğitimine ilişkin literatürde temel eğilim insan hakları eğitimini bazen kapsamı bakımından bazen de amaçları bakımından "insan hakları hakkında öğrenme" (learning about human rights) ve "insan hakları için öğrenme" (learning for human rights) şeklinde ikiye ayırarak incelemek yönündedir (Flowers vd., 2000, s.10-13; Lohrenscheit, 2002, s.176). Farklı bakışlara göre bu yöntemlerden biri tercih edilebileceği gibi aşamalı olarak ikisi bir bütün olarak da kabul edilebilmektedir. Buna göre ilk olarak "insan hakları hakkında eğitim” insan hakları tarihini, bu alandaki belgeleri ve uygulama mekanizmalarını kapsayan kişilere bu çerçevede bilgiler sunan bir eğitimdir. 14 Mayıs 1985 tarihli Avrupa Konseyi Tavsiye Kararı'nda insan hakları hakkında eğitimin kapsamına giren konulardan bazıları; "insan haklarının temel kategorileri”, “adaletsizlik, eşitsizlik ve ayrımcılık türleri”, "insan hakları mücadelesi”, "temel uluslararası bildirgeler ve sözleşmeler” olarak sıralanmıştır (Council Of Europe, 1985, s. 3).

Buna göre temel insan hakları hakkında eğitim almış bir kişi temel insan hakları kavramını ve onunla ilişkili kavramları ve ilgili belgelerini tanır, bu belgelerde adı geçen hakları bilir ve bu hakların korunması için oluşturulmuş ulusal ve uluslararası mekanizmalar hakkında fikir sahibi olur. Kişilerin insan hakları alanındaki "bilgi birikimini ve bilişsel becerilerini” geliştirmeyi amaçlayan bu eğitim insan hakları alanında temel düzeyde bilgi sağlaması açısından önemlidir (Lohrenscheit, 2002, s.176).

İkinci olarak "insan hakları için öğrenme" kavramı ise insan onuru ve eşitlik gibi temel prensiplerin benimsenmesi ile insan haklarının korunması için olumlu yönde niyet geliştirmeyi sağlayacak eğitimi anlatmak için kullanılan bir kavramdır (Flowers vd., 2000, s. 13). Bu eğitimin 
temel amacı "güçlendirilmiş ve aktif bireyler" yetiştirmektir. Güçlü birey toplumsal gelişmeye destek olan bireysel ihtiyaçlarını tanıyan ve insan haklarına uygun şekilde toplumsal gelişmeye destek olan kişidir (Lohrenscheit, 2002, s. 176). "İnsan hakları için öğrenme" dayanışmayı ve hoşgörüyü geliştirerek kişilerin savunuculuk yeteneklerini ortaya çıkaracak bir eğitim olarak tanımlanmaktadır (Flowers vd., 2000, s.13).

Benzer şekilde Kuçuradi, "insan haklarının etik eğitimi” olarak adlandırdığı iki aşamalı bir eğitimden söz etmektedir. Bu eğitim "insan hakları ihlal edilmeden önce, insan hakları ihlal edilemeyecek tarzda eylemde bulunmayı istemeyi" kapsayan bir eğitimdir ve bu istemeyi kazanabilmek için "insan olma bilinci" ne sahip olmak gerekmektedir. Kuçuradi (2004b, s.376) bu bilincin "belirli bazı insansal olanakların değerinin bilgisiyle sunulmasılla" ve "insan haklarının bilgisinin sunulmasılla" edinilebileceğini belirtmektedir.

Diğer taraftan insan hakları eğitimi alanında yer alan çalışmalar insan hakları eğitiminin her öğretim düzeyinde gerçekleşmesi gerektiğini ortaya koymaktadır. BM kaynaklarından hareketle oluşturulmuş eğitim programında erken çocukluk döneminden başlayarak yetişkinlik dönemine dek sürmesi gereken insan hakları eğitiminin amaçları, uygulamaları ve program kapsamında ele alınması gereken problemler genel hatlarılla şöyle belirlenmiştir:

3-7 yaş aralı̆̆ını kapsayan dönemde temel amaç; çocuğun "kendine, ebeveynlerine, öğretmenlerine ve diğerlerine" saygı duymasıdır. Bu dönemde kullanılacak anahtar kavramlar ise; "öz/kişi, topluluk ve sorumluluk" kavramlarıdır. Bu döneme has ele alınacak insan hakları problemleri ise "rrkçllk", "cinsiyetçilik", "adaletsizlik" ve "insanlara duygusal veya fiziksel bakımdan zarar vermek" olarak sıralanmıştır (Flowers vd., 2000, s.14).

8-11 yaş aralığındaki çocuklar için insan hakları eğitiminin amaçları "sosyal sorumluluğun" gelişmesi ve "ihtiyaç-istek ayrımının" yapılabilmesidir. Bu dönemdeki önemli kavramlar; "kişi hakları, grup hakları, özgürlük, eşitlik, adalet, hukukun üstünlüğü, hükümet, güvenlik, demokrasi" olarak belirlenmiştir. Ele alınacak insan hakları sorunları ise "ayrımclık/önyargı, yoksulluk/açlık, adaletsizlik, etnik merkezcilik” olarak sıralanmıştır (Flowers vd., 2000, s.14). 12-14 yaş grubunda ise amaç bazı haklar üzerinde ayrıntılı bilgiye sahibi olmaktır. Bu yaş grubu için önemli kavramların "uluslararası hukuk, dünya barışı, dünyanın kalkınması, dünya politik ekonomisi, dünya ekolojisi, hukuki haklar ve ahlaki haklar" kavramları olduğu belirtilmiştir. Bu dönemde üzerinde durulacak insan hakları sorunlarına ise "cehalet", "sömürgecilik/emperyalizm" ve "çevresel bozulma" örnek olarak verilebilir (Flowers vd., 2000, s.14).

15 yaş ve üstü için insan hakları eğitiminde temel amaç; insan hakları ile ilgili temel bilgilere sahip olmak ve bu bilgileri davranışa dönüştürebilmektir. Bu dönemde "soykırım" ve "işkence" gibi sorunların üzerinde durulmaktadır (Flowers vd., 2000, s.14)2.

\footnotetext{
2 Benzer bir başka çalışma için bkz: Reardon, 1995, s.14
} 
Kuçuradi de ilkokul düzeyinde öğrencilerde "insan kimliği bilinci” uyandırılması gerektiğini, ortaokulda ise yine bu bilince önem verilmesi gerektiğini aynı zamanda bu bilincin bilgiye dönüştürülmesi gerektiğini dile getirmektedir. Ayrıca Kuçuradi, insan hakları araştırmalarının teşvik edilmesi gerektiğini ve bu kapsamda "lisansüstü düzeyde insan hakları eğitiminin geliştirilmesi” gerektiğini savunmaktadır (2004b, s.378).

\section{İnsan Hakları Eğitiminin Gündeme Taşınması}

İnsan hakları eğitimi "eğitim, öğretim ve evrensel bir insan hakları kültürü oluşturmayı hedefleyen bilgiler" olarak tanımlanabilir (UNESCO, 2017, s.2). Kavramsal olarak "İnsan Hakları Eğitimi” konusunun uluslararası ve ulusal alanda gündeme taşınması II. Dünya Savaşı sonrasında olmuştur. Bu süreçte ele almamız gereken temel belgeler ve gelişmeler şöyledir: 1948 “İnsan Hakları Evrensel Bildirisi”.

1974 Birleşmiş Milletler Eğitim, Bilim ve Kültür Örgütü (UNESCO) “İnsan Hakları ve Temel Özgürlüklerine İlişkin Uluslararası Anlayış, İşbirliği ve Barış için Eğitim Tavsiye” Kararı.

1978 “UNESCO Uluslararası İnsan Hakları Öğretimi Kongresi”.

1987 Malta “UNESCO Uluslararası İnsan Hakları Öğretimi, Bilgi ve Belgeleri Kongresi”,

1993 “Uluslararası İnsan Hakları ve Demokrasi Eğitimi Kongresi” .

Belgelerden ve belgelere ilişkin bazı önemli noktalardan bahsedecek olursak:

1948 tarihli İnsan Hakları Evrensel Bildirisi (İHEB)'nin hemen giriş kısmında Bildiride yer alan hak ve özgürlüklere "eğitim ve öğretim” yoluyla saygının geliştirilmesi gerektiği belirtilmiştir ve bu çerçevede eğitimin insan haklarının yaygınlaşmasındaki önemine değinilmiştir. Yine bildirinin 26. maddesinde "Eğitim insan kişiliğini tam geliştirmeye ve insan haklarıyla temel özgürlüklere saygıyı güçlendirmeye yönelik olmalıdır. Eğitim, bütün uluslar, ırklar ve dinsel topluluklar arasında anlayış, hoşgörü ve dostluğu özendirmeli ve Birleşmiş Milletlerin barışı koruma yolundaki çalışmalarını geliştirmelidir" ifadesine yer verilerek eğitimin insan haklarıyla olan ilişkisi vurgulanmıştır (İnsan Hakları Evrensel Bildirisi, 1948, s.26).

1974 tarihli "İnsan Hakları ve Temel Özgürlüklerine İlişkin Uluslararası Anlayış, İşbirliği ve Barış için Eğitim Tavsiyesi” nde ise İHEB’ in 26. maddesinde yer alan “Eğitim insan kişiliğini tam geliştirmeye ve insan haklarıyla temel özgürlüklere saygıyı güçlendirmeye yönelik olmalıdır. Eğitim, bütün uluslar, ırklar ve dinsel topluluklar arasında anlayış, hoşgörü ve dostluğu özendirmeli ve Birleşmiş Milletlerin barışı koruma yolundaki çalışmalarını geliştirmelidir” ifadesinin altı çizilerek her seviyedeki ve her formdaki eğitimi kapsayacak şekilde eğitim politikalarının temel prensipleri ortaya konulmuştur. Bu prensiplerden bazılarına göre, "her türlü kültüre, medeniyete, değere, yaşam şekline" saygı duyulacaktır. "Küresel karşılıklı bağımlılık bilinci" temelinde hareket edilecek ve "sadece haklar değil aynı zamanda sorumluluklar” da dikkate alınacaktır (UNESCO, 1974). 
1978 “UNESCO Uluslararası İnsan Hakları Öğretimi Kongresi” bu alandaki bir diğer önemli gelişmedir. Kongreye ilişkin metnin giriş kısmında insan hakları eğitimi için "öğretmenleri, eğitimcileri, savunucuları, uzmanları ve birbirinden farklı düşüncelere sahip hükümet temsilcilerini” bir araya getiren söz konusu kongrenin bu alanda bir “dönüm noktası” olduğu belirtilmektedir. İnsan haklarının üniversite öğretimini geliştirmek için alanda üç çeşit eğitimin teşvik edilmesinin söz konusu olduğu belirtilmiştir. Bu eğitimler: "insan haklarında temel eğitim, insan haklarında uzmanlık eğitimi ve insan hakları eğitimidir” (UNESCO, 1978, GirişPreface). Kongreye ilişkin belgenin ilerleyen bölümlerinde ise insan haklarına ilişkin eğitim ve öğretiminin “Birleşmiş Milletler Anlaşması'na, İnsan Hakları Evrensel Bildirisi'ne, Uluslararası İnsan Hakları Anlaşmalarına ve diğer uluslararası insan hakları mekanizmalarına” dayanması gerektiği belirtilmiştir. Bu arada belgede hakların bölünmezliğine de dikkat çekilmiştir. İnsan hakları eğitiminin "geleneksel yöntemlerin" yanı sıra "tarihsel deneyimleri” de kapsaması gerektiğine ayrıca değinilmiştir. Eğitimin kişilerde hem kendi haklarını hem de başkalarının haklarını korumaları yönünde "bilinç geliştirmesi” gerektirdiği belirtilmiştir. Yine insan hakları konusunun "profesyonel, etik ve sosyal sorumluluk gerektiren bir araştırma, çalışma ve eğitim alanı" olduğunun altı çizilmiştir. Eğitimin insan haklarına saygı çerçevesinde gerçekleştirilmesi değil insan hakları eğitiminin geliştirilmesi ve bu eğitimin özellikle” felsefe, siyaset bilimi, hukuk gibi alanlara entegre edilerek" bağımsız bir şekilde öğretilmesi gerektiği belirtilmiştir (UNESCO, 1978, s.40-41).

İnsan hakları ve eğitim konusunda önemli bir diğer gelişme de 1987 tarihinde Malta'nın başkenti La Valette'de gerçekleşen “UNESCO Uluslararası İnsan Hakları Öğretimi, Bilgi ve Belgeleri Kongresi”dir. Kongrenin amaçları: "insan hakları öğretimindeki mevcut yönelimleri tespit etmek; ilgili kuruluşlara, sivil toplum örgütlerine tavsiyelerde bulunmak; sosyal ve beşeri bilimler alanında araştırma konuları önermek; UNESCO, sivil toplum örgütleri ve dokümantasyon merkezleri için en uygun eylem planlarını önermek ve sonraki dönem için sürdürülecek eylem planlarına karar vermek" olarak belirtilmiştir (UNESCO, 1987, s.5). Kongrede; insan hakları eğitiminin amaçları ve hedefleri, içeriği, yöntemleri, öğretim materyalleri gibi konular üzerinde durulmuştur. Yine, öğretmenlerin eğitimi, öğretmenlerin ve eğitimcilerin korunması, insan hakları ve insan hakları eğitimi alanında araştırmaların ve uluslararası işbirliklerin geliştirilmesi gibi konular da kongrede ele alınan diğer konu başlıkları arasında yer almıştır (UNESCO, 1987).

1993 yılında Birleşmiş Milletler (BM) kapsamında Montreal'de gerçekleşen “Uluslararası İnsan Hakları ve Demokrasi Eğitimi Kongresi" ve bu kongrede ortaya konulan "İnsan Hakları ve Demokrasi Eğitimine Yönelik Dünya Eylem Planı” insan hakları ve eğitim açısından önemli bir diğer gelişmedir. Kongrenin temel amaçları; insan hakları eğitimi alanındaki engelleri tanımlamak ve bunlarla başa çıkmak, "demokrasi için eğitim” konusunu tamamlayıcı bir bağlamda ele almak ve "insan hakları ve demokrasi için eğitime yeni bir ivme kazandırmak için, özellikle eğitim yöntemleri, pedagojik yaklaşımlar ve didaktik materyaller olmak üzere araç ve fikirlerin detaylandırılmasını teşvik etmek” olarak sıralanmıştır (UNESCO, 1993, s.6). Bu çerçevede kongrede insan hakları ve temel özgürlüklerin korunmasının demokratik değerlere bağlı olduğu, bu demokratik değerlere eğitimle erişilebileceği, demokrasi ve insan hakları 
eğitiminin de bir insan hakkı olduğu gibi konulara dikkat çekilmiştir (UNESCO, 1993, s.9). Kongrede ortaya konan eylem planında eğitimin üç farklı düzeyde geliştirilmesi öngörülmüştür. Buna göre ilk olarak insan hakları eğitiminin "okul sistemi içinde tüm seviyelerde" olmak üzere "ilkokul öncesinden başlayarak yükseköğrenimi, mesleki eğitimi, öğretmen ve ebeveyn örgütlenmelerini” de kapsayacak şekilde öğretim programlarına dâhil edilmesi gerekmektedir. İkinci olarak "okul dışında" insan hakları ve demokrasi eğitiminin yaşamın farklı alanlarına dâhil edilmesi öngörülmüştür. Buna göre, "işyerlerinde, dini ve kültürel örgütlerde, gençlik kulüpleri” gibi alanlarda gerçekleştirilecek eğitimlerle "sosyal yaşama yeterince katılamayan kişilerin; kamu personelinin, karar alıcıların; askeri personelin, güvenlik konusunda hizmet verenlerin; hâkim, savcı ve avukatların; medya personelinin; tıp doktorları, sağlık çalışanları ve biyolojik araştırmacıların” eğitilmesi gerekmektedir. Üçüncü olarak odaklanılan ise "hakları tehlikede olan" kişilerin bilgilendirilmesi ve eğitilmesidir. Bu çerçevede verilecek eğitimin kapsamı örneğin "silahlı çatışma” ya da "doğal afetler" gibi durumlara maruz kalınması hallerinde ve "kadınlar çocuklar, engelliler, azınlıklar" gibi dezavantajlı gruplara yönelik gerçekleşecektir (UNESCO, 1993, s.17-18).

Uluslararası alanda insan hakları eğitimini gündeme taşıyan gelişmeler bu örneklerle sınırlı değildir. Ana teması insan hakları eğitimi olmasa da başka birçok uluslararası etkinlikte ve insan haklarıyla ilişkili toplantıda "insan hakları eğitimi" konusu önemli bir başlık olarak tartışılmıştır. Uluslararası alanda yaşanan bu gelişmeler zamanla ulusal alanda da karşılık bulmuştur.

\section{Türkiye'de İnsan Hakları Eğitimi}

Uluslararası alanda insan hakları eğitimi konusunda yaşanan gelişmelere paralel olarak Türkiye'de insan hakları dersinin ilköğretim ve orta öğretim programlarına girmesi, ayrı bir ders haline gelmesi ve insan hakları konusunun yükseköğretimde gündeme gelmesi 1991 yılı sonrasında olmuştur. Bu süreç içinde ele alınması gereken ilk gelişme, TBMM İnsan Haklarını İnceleme Komisyonu (İHİK)'nun girişimleri; ikincisi ise İnsan Hakları Eğitimi Protokolü’nün hazırlanmasidır.

Süreç İHİK’in 1991 yılında Milli Eğitim Bakanlığı’ndan insan hakları eğitimi konusunda görüş almak için yazı yazmasıyla başlamıştır (Gülmez,1996, s.221). Komisyonun 15 Mayıs 1991 tarihinde "ilk ve orta dereceli okullarda" ders programlarına "insan hakları eğitimi ile ilgili bir ders konulması" konusunda bakanlığa göndermiş olduğu yazı, olumsuz yanıt almıştır. Milli Eğitim Bakanlığı insan hakları konusunun başkaca ders programları içinde yer aldığını belirtmiş ve ayrı bir ders olarak öğretim programına eklenmesine gerek olmadığını ifade etmiştir. Komisyon 1993 yılında talebini tekrar dönemin Milli Eğitim Bakanı'na iletmiştir. Bakanlık bir önceki dönem bakanının da ifade etmiş olduğu gibi "ilkokul, ortaokul ve liselerde ilgili derslerin öğretim programlarında "insan hakları konusunun yeterince yer aldığını ve bağımsız bir derse gerek olmadığını” dile getirmiştir (Gülmez, 1996, s. 223). 
İnsan hakları konusunun bağımsız bir ders olarak eğitim sistemine dâhil edilmesine neden olan gelişme ise 1995 yllında gerçekleşmiştir. 14 Mart 1995 tarihinde "İnsan Haklarından Sorumlu Devlet Bakanlı̆̆ı" ile "Milli Eğitim Bakanlı̆ı̆”nca düzenlenen "İnsan Hakları Eğitimi Protokolü" dönemin başbakanı, dışişleri bakanı ve ilgili bakanlar tarafından imzalanmıştır (Gülmez, 1996, s.226). İlgili protokol ile ilköğretime, ortaöğretime ve yükseköğretime insan hakları konusunun dâhil olabilmesi için bir takım düzenlemeler öngörmüştür. Buna göre: Protokol kapsamında ilköğretim programlarında yer alan "Vatandaşlık Bilgileri” dersinin ismi "Vatandaşılı ve İnsan Hakları Eğitimi” olacak ve dersin kapsamı yeniden şekillendirilecektir. Ayrıca ortaöğretim programlarına "Demokrasi ve İnsan Hakları" dersi dâhil edilecektir. Yükseköğretimde ise insan hakları dersi "üniversitelerin öncelikle öğretmen yetiştiren fakülte ve yüksekokullarında formasyon kazandıran dersler" arasına eklenecektir. Yine bu çerçevede "insan hakları sertifikası" adında bir sertifika programı da edebiyat ve fen-edebiyat fakültelerinde "öğretmen olmak isteyen öğrenciler" için geliştirilecektir. Ayrıca sosyal bilimler enstitüleri içinde "insan hakları anabilim dalı" kurulması planlanmıştır (Gülmez, 1996, s.227-228).

1995 yllındaki protokolü takiben insan hakları eğitiminde önemli atılımlar olmuştur. Örneğin; 1995 yılının Mart ayında alınan kararla 8. Sinıflarda okutulan "Vatandaşlık Bilgileri " dersi "Vatandaşılı ve İnsan Hakları" adını almıştır (Milli Eğitim Bakanlığı Tebliğler Dergisi, 19952437, s.696-697). Yine 1996 yılında ilgili dersin içeriği yurttaşlık bilgilerinin yanı sıra "insan hak ve hürriyeti, sorumlulukları; kişi hürriyeti, kişi hürriyetinin önemi; vatandaşlık ödevleri; Türk kadının toplumdaki yeri” gibi konuları da kapsayacak şekilde düzenlenmiştir (Milli Eğitim Bakanlığı Tebliğler Dergisi, 1996 Temmuz-2457, s.448-453). 1999 yllında ise Milli Eğitim Bakanlığı Tebliğler Dergisi'nde yer alan haliyle liselerde uygulanacak "Demokrasi ve İnsan Hakları" dersinin içeriği "insan hakları, hukuk ve devlet; yönetim ve yaşam biçimi olarak demokrasi; insan hakları ve korunması; Atatürk İnkılabı; insan hakları ve demokrasi” olarak belirlenmiştir (Milli Eğitim Bakanlığı Tebliğler Dergisi, 1999-2501, s.321-332).

Bugün mevcut eğitim sistemine bakacak olursak; 2018-2019 eğitim öğretim yllında yenilenen haliyle ilköğretim programlarında, ilkokul 4. sinıflarında "İnsan Hakları, Yurttaşlık ve Demokrasi" dersinin yer almakta olduğu görülmektedir. Dersin içeriği sırasılyla "insan olmak; hak, özgürlük ve sorumluluk; adalet ve eşitlik; uzlaşı; kurallar; birlikte yaşama" konularını kapsamaktadır (Milli Eğitim Bakanlığı, 2018a, s.10). Ayrıca 2018-2019 eğitim-öğretim yılından itibaren geçerli olacak "ortaöğretim kurumları haftalık ders programına" göre "Demokrasi ve İnsan Hakları” dersi Fen Liseleri'nde ve Anadolu Liseleri’nde 9, 10, 11, 12 sinıflar için seçmeli dersler arasında yer almaktadır. Sosyal Bilimler Liseleri'nde ise "Demokrasi ve İnsan Hakları" dersi 9. Sınıflar için seçmeli dersler arasında yer almaktadır. Güzel Sanatlar Liseleri'nde 9, 11 ve 12. Sinıflarda; spor lisesinde ise 11. ve 12. Sinıflarda ilgili ders seçmeli dersler arasında bulunmaktadır. "Demokrasi ve İnsan Hakları" dersi Anadolu İmam Hatip ve Uluslararası İmam Hatip Liselerinde de seçmeli dersler arasında yer almaktadır (Milli Eğitim Bakanlığı, 2018b). 
Yükseköğretimde ise aynı konunun gündeme taşınması yine 1991 yllında İHİK’in yüksekokullara öğretim programlarında insan hakları dersi olup olmadığı konusunda ve eğer varsa bu dersin kapsamı hakkında bilgi verilmesi hususunda göndermiş olduğu yazıya dayanmaktadır. İlgili yazıya cevaben Ankara Üniversitesi Eğitim Bilimleri Fakültesi Dekanlığı, fakültelerinde "İnsan Hakları ve Demokratik Kurumlar" dersinin yer almakta olduğunu belirtmiştir (Gülmez, 1996, s.222). Bu örnek bize yükseköğretimde insan hakları dersinin söz konusu girişimlerden önce de yer almakta olduğunu göstermektedir. Bu konuda başkaca örnekler ise: 1975 yllında “Türkiye ve Ortadoğu Amme İdaresi Enstitüsü” (TODAİE)'nde İnsan Hakları Araştırma ve Dokümantasyon Merkezi'nin ve yine 1978 yilında Ankara Üniversitesi bünyesinde İnsan Hakları Uygulama ve Araştırma Merkezi'nin kurulmuş olmasıdır.

Ancak 1990 sonrasinda yükseköğretimde insan hakları eğitimi konusunda başkaca önemli gelişmeler de yaşanmıştır. Örneğin 1997 yılında "Hacettepe Üniversitesi" bünyesinde "İnsan Hakları Felsefesi Uygulama ve Araştırma Merkezi” kurulmuştur. Bu gelişmeyi takiben Sosyal Bilimler Enstitüsüne bağlı olarak "İnsan Hakları Anabilim Dalı" altında Hacettepe Üniversitesi yüksek lisans ve doktora eğitimlerine başlamıştır. 2000 yılında Bilgi Üniversitesi’nde "İnsan Hakları Hukuku Araştırma ve Uygulama Merkezi” açılmıştır. Bilgi Üniversitesi Sosyal Bilimler Enstitüsü’ne bağlı olarak “İnsan Hakları Hukuku” yüksek lisans programı da mevcuttur³. Yine, 2005 yllında Maltepe Üniversitesi’nde “İnsan Hakları Araştırma ve Uygulama Merkezi” açılmış ve ilgili enstitüye bağlı olarak merkez bünyesinde yüksek lisans eğitimine başlanmıştır.

Günümüzde yükseköğretimde insan hakları dersi çoğunlukla eğitim fakültelerinde; iktisadi ve idari bilimler, siyasal bilgiler, işletme fakültelerinde seçmeli ders olarak yer almaktadır. Sağlık Bilimleri Fakültelerine bağlı olarak sosyal hizmetler programlarında da insan hakları dersi seçmeli ders olarak yer almaktadır. Yine hukuk fakültelerinde de "insan hakları hukuku" dersi bulunmaktadir.

\section{Kamu Yönetimi Eğitimi}

\section{Kamu Yönetimi Eğitiminin Kapsamı}

Her mesleğin icrasında en önemli mesele o mesleği icra edecek nitelikli personelin yetiştirilmesidir. Kamu yönetimi alanında da bu durum her zaman dikkate alınmış ve "devletler bu gereksinimlerini karşılamak üzere çeşitli öğretim kurumları yaratmışlardır” (Altan, Kerman ve Aktel, 2009, s.228). Kamu yönetimi alanında nitelikli ve kaliteli eğitim hem "kamu istihdamının daha iyi hizmet vermesine" hem de "kamu görevlilerinin daha iyi hizmet vermelerine" yol açmaktadır. Bu durum da zorunlu olarak kamu yönetimi eğitiminin bir disiplin haline gelmesine yol açmıştır (Çiner, 2015, s.4).

Kamu yönetimi eğitimi "kamu yönetimi üzerine akademik eğitim" ve "kamu yönetimi içinde gerçekleşen hizmet içi eğitim" olarak ele alınabilmektedir (Parlak, 2015, s.5). Bu çalışmada odaklanılan kamu yönetimi eğitimi "kamu yönetimi üzerine akademik" eğitimdir. Akademik

\footnotetext{
${ }^{3}$ İnsan Hakları Hukuku yüksek lisans programı, Galatasaray Üniversitesi, Dokuz Eylül Üniversitesi gibi üniversitelerde de mevcut bir yüksek lisans programıdır.
} 
bakımdan kamu yönetimi eğitimi "üniversitelerin kamu yönetimi, siyaset bilimi ve kamu yönetimi vb. adı taşıyan bölümleri ve bu bölümlerde verilen eğitim ve öğretim faaliyetleri" ve bu adı taşıyan bölümler dışında "ilgili bölümlerde verilen kamu yönetimi alanına dâhil dersler" olarak tanımlanmaktadır (Parlak, 2015, s.56). Ancak tanımı derinleştirmek için dersler üzerinden bir tanımlama yapmak mümkün görünmemektedir. Zira kamu yönetimi eğitimi kapsamına giren dersler konusunda bir ortaklıktan ziyade farklılık söz konusudur. Parlak (2015, s.56), bu farklılıkların "kayda değer" olduğunu belirtmekte ve bu nedenle "toplumsal yarar ve özel anlamda öğrenciler bakımından kamu yönetimi eğitiminin işlevsel ve yararlı olabilmekten" uzaklaştığını ifade etmektedir. Kamu yönetimi programlarında ortak bir öğretim programının eksikliği daha önceleri de fark edilmiş ve bu durum Yükseköğretim Kurulu (YÖK) tarafından "Kamu Yönetimi Bölümü Lisans Programı İçin Önerilen Çerçeve Program" adıyla 1983 yllında hazırlanmış olan öğretim programılla çözülmeye çalışılmıştır. Bu öğretim programına göre kamu yönetimi bölümlerinde yer alması tavsiye edilen zorunlu dersler şöyledir (Kaya, 1995, s.261):

"Atatürk İlkeleri ve İnkılap Tarihi I-II-III-IV, Türkçe I-II-III-IV, İktisada Giriş I-II, Hukukun Temel Kavramları, Siyaset Bilimine Giriş, Toplum Bilimi I-II, Anayasa Hukukuna Giriş, Siyasal Düşünceler Tarihi I-II, İdare Hukuku, Kamu Maliyesi, Yönetim Bilimi I-II, İktisadi Sistemler, Maliye Teorisi, Makro İktisat, Sosyal Bilimlerde Yöntem, Türkiye'nin Toplumsal Yapısı, Çağdaş Devlet Düzenleri, Türk Anayasa Düzeni, Mahalli İdareler, Uyrukluk ve Yabancılar Hukuku, Mahalli İdareler Maliyesi, Türk Siyasal Hayatı I-II, Kamu Personel Yönetimi, Siyaset Sosyolojisi, Türkiye Ekonomisi, İnsanlık Tarihi I-II, Türk Yönetim tarihi, Siyaset Psikolojisi ve İdari Yargi".

Seçmeli dersler ise: "Beşeri Kaynaklar Ekonomisi, Bölge Planlaması ve Çevre Koruması, Bütçe, Ceza Hukuku ve Kriminoloji, Ceza Yargılama Hukuku, Çağdaş Siyasal Akımlar, Çalışma Ekonomisi, Çevre Sorunları, Devlet Muhasebesi (Milli Bütçe), Doğal Kaynaklar Ekonomisi, Hazine İşlemleri, İktisadi Gelişme ve Vergileme, İktisadi Planlama, İş Hukuku, Kalkınma İktisadı, Kamu İktisadi Teşebbüsleri, Kamu Örgütlerinde Mali Denetim, Kentleşme ve Konut Politikası, Kooperatif̧̧ilik Teorisi, Mali Kurumlar; Bankacılık, Mali Yargı, Para Teorisi, Parafiskal Yükümlülükler, Personel Yönetimi, Sosyal Güvenlik ve Gelir Dağılımı, Sosyal Planlama, Sosyal Politikaya Giriş, Sosyal Psikoloji, Türk-İslam Düşünce Tarihi, Uluslararası Maliye, Ücretler ve Gelirler Politikası, Vergi Hukuku I-II" olarak sıralanmıştır.

Sözü geçen çerçeve programın hazırlanmasından 32 sene sonra 2015 yılında yine ilgili programlarda bulunması gereken zorunlu ve seçmeli derslere ilişkin bir öğretim programı çalışması daha yapılmıştır. 13 Aralık 2015 tarihinde Isparta'da Süleyman Demirel Üniversitesi İktisadi ve İdari Bilimler Fakültesi'nde gerçekleşen Kamu Yönetimi Çalıştayı’nda ortaya çıkan görüşlere göre ilgili programlarda bulunması gereken zorunlu dersler:

"Kamu Yönetimi Kuramları (ya da Yönetim Bilimi), Araştırma Yöntem ve Teknikleri, Türk Kamu Yönetimi, Yerel Yönetimler, Kamu Politikası, Kamu Personel Yönetimi, Türk Anayasa 
Düzeni, Karşılaştırmalı Siyasal Sistemler, Hukuka Giriş, İdare Hukuku, İnsan Hakları, Ceza Hukuku, Siyaset Bilimine Giriş, Türk Siyasi Hayatı, Siyasal Düşünceler Tarihi, Siyasi Tarih, Kentleşme ve Konut Politikası, Çevre Bilimi, Mikro İktisat, Makro İktisat, Türkiye Ekonomisi, Kamu Maliyesi, Avrupa Birliği ve Türkiye'nin Toplumsal Yapısı (ya da sosyoloji)” olarak sıralanmıştır.

Seçmeli dersler ise şöyledir: "Karşılaştırmalı Kamu Yönetimi, Yerel Yönetimler Maliyesi, Halkla İlişkiler, Yerel Siyaset, Dünyada Yerel Yönetimler, AB’de Yerel Yönetimler, İstatistik, Kamu Yönetiminde Reform, Vergi Hukuku, Devlet Bütçesi, Vatandaşlık Hukuku, Uluslararası Hukuk, İş Hukuku, Borçlar hukuku, Ticaret Hukuku, Genel Muhasebe, Güvenlik Yönetimi, Kriz Yönetimi, Mesleki Vizyon, Kamu Yönetimi ve Özel-Sivil Sektör İlişkileri, Mali Yönetim ve Denetim, Kamu Yönetiminde Etik, Müzakere Yönetimi, Kalite Yönetimi, Çağdaş Siyasal İdeolojiler, Siyaset Psikolojisi, Toplumsal Cinsiyet Çalışmaları” (Gül vd., 2017, s. 7).

Görüldüğü üzere 1983 yılında hazırlanmış olan "Kamu Yönetimi Bölümü Lisans Programı İçin Önerilen Çerçeve Program" içinde "İnsan Hakları" dersi ya da insan hakları konusuyla ilişkili herhangi bir ders yer almamaktadır. Ancak 2015 yılında gerçekleştirilen Kamu Yönetimi Çalıştayı'nda "İnsan Hakları” dersi zorunlu dersler arasında sıralanmıştır. Buradan hareketle kamu yönetiminin gelişimini takiben bir sonraki bölümde adında "kamu yönetimi" ifadesi bulunan lisans programlarının öğretim programlarında insan hakları dersinin ve insan hakları konusuyla ilişkili derslerin yer alıp almadığına ve ne şekilde (zorunlu/seçmeli) yer aldığı analiz edilecektir.

\section{Kamu Yönetimi Eğitiminin Gelişimi}

Tarihi çok daha eskilere dayansa da yönetim bilimi, 19. yüzyıldan itibaren ayrı bir disiplin olarak kabul görmeye başlamıştır. Yönetim biliminin akademik bir alan olarak kabul edilerek hakkında incelemeler yapılmaya başlanmasının Amerika Birleşik Devleti açısından ilk örneği; 1887 yılında Woodrow Wilson tarafından yazılan ve "Political Science Quarterly" dergisinde yayınlanan "The Study of Administaration (Yönetimin İncelenmesi)" adlı makaledir. Bu gelişmeyi takiben yayınlanan "Frank J. Goodnow'un Politics and Administration (Siyaset ve Yönetim) ile Leonard D. White'ın Introduction to the Study of Public Administaration (Kamu Yönetiminin İncelemesine Giriş)” adlı eserler kamu yönetimi alanının gelişmesine önemli katkılar sağlamışlardır (Parlak, 2015, s. 67). Diğer taraftan Avrupa'da ise 18. Yüzyılda Prusya’da gelişim gösteren "Kameral Bilimler" adlı kürsüler kamu yönetiminin bağımsız bir alan olarak gelişmesinin önemli örneklerinden biridir. Söz konusu kürsülerin amacının "yönetime iyi yetişmiş insan gücü kazandırmak” olduğu belirtilmiştir (Parlak, 2015, s.70).

Türkiye'de ise kamu yönetimi uzun zaman “idare hukukunun bir alt alanı” olarak görülmüş ve bu nedenle de "hukuk profesörlerinin bir konusu olarak" kabul görmüştür (Kaya, 1995, s.253). 1953 yılında TODAİE’nin kurulması ve enstitü bünyesinde kamu görevlilerine yönelik eğitim programlarının geliştirilmesiyle kamu yönetimi eğitimi farklılaşmaya ve bağımsızlaşmaya başlamıştır. Bu gelişmenin ardından 1957'de Ankara Üniversitesi Siyasal Bilgiler Fakültesi 
bünyesinde “Amme İdaresi Kürsüsü” kurulmuştur (Kaya, 1995, s.254). Bu dönemi takiben yaklaşık 25 sene kamu yönetimi eğitimi açısından önemli bir gelişme yaşanmamıştır. Söz konusu durağanlık YÖK’ün 1981 yılında kurulmasıyla yerini önemli gelişmelere bırakmıştır.

Türkiye'de yükseköğretimde kamu yönetiminin kurumsal gelişimini Ömürgönülşen (2010, s.126-129), üç dönemde incelemektedir. Bu dönemler "YÖK öncesi dönem”, "YÖK’le birlikte Kamu Yönetimi Öğretimi Yapan Yükseköğretim Kurumlarında Artış ve Standartlaşma Dönemi” ve "Gelişmekte Olan ve Yeni Kurulan Üniversitelerle Kamu Yönetimi Öğretiminin Yurt Çapında Yaygınlaştığı Dönem” olarak dile getirilmiştir.

İlk dönemde kamu yönetimi öğretiminde başı çeken kurum Ankara Üniversitesi Siyasal Bilgiler Fakültesi (AÜ SBF)'dir. AÜ'de eğitim SBF bünyesinde İdari Şube'de Siyaset ve İdare Bilimleri Bölümü'nde gerçekleşmektedir. Daha sonra Ortadoğu Teknik Üniversitesi, İdari Bilimler Fakültesi Amme İdaresi Bölümü açılmıştır. Bu gelişmeleri “Boğaziçi Üniversitesi, İstanbul Üniversitesi, Ankara İktisadi ve Ticari İlimler Akademisi, İstanbul İktisadi ve Ticari İlimler Akademisi ve Türkiye Ortadoğu Amme İdaresi Enstitüsü” bünyelerinde açılan ilgili bölümler ve dersler izlemiştir (Ömürgönülşen, 2010, s.131).

İkinci dönem 1980 sonrasında YÖK’un kurulması ile başlamıştır. 1981 yılında Yükseköğretim Kanunu'nun çıkartılması ve YÖK’ün oluşturulmasıyla köklü değişiklikler yapılmış ve yükseköğretim kurumları yeniden düzenlenmiştir. Söz konusu düzenlemeler arasında akademilerin üniversitelere dönüştürülmesi, eğitim enstitülerinin ise eğitim fakültelerine dönüştürülmesi gibi önemli değişiklikler yer almaktadır (URL 1). Bu gelişmelere paralel olarak AÜ SBF, İstanbul Üniversitesi Siyasal Bilgiler Fakültesi ve "Boğaziçi, Dokuz Eylül, Gazi, Hacettepe, İnönü, Marmara, ODTÜ ve Uludağ Üniversitelerinde” İktisadi ve İdari Bilimler Fakülteleri altında Kamu Yönetimi bölümleri kurulmuştur (Ömürgönülşen, 2010, s.131). Bu dönemdeki önemli bir diğer gelişme de YÖK tarafından "Kamu yönetimi bolümü lisans programı için çerçeve program” önerilmesidir. Böylelikle kamu yönetimi eğitiminde yaygınlaşmanın yanı sıra standartlaşma yönünde de adım atılmış olduğu belirtilmektedir (Aktaran Ömürgönülşen, 2015, s.131).

Üçüncü dönem ise 1990 sonrası dönemi işaret etmektedir. Bu döneme damgasını vuran gelişme yeni kurulan ya da yeni gelişmekte olan devlet ve vakıf üniversitelerinde kamu yönetimi bölümlerinin açılmasıdır (Ömürgönülşen, 2010, s.131). 1990 sonrasında öncelikle "Akdeniz, Atatürk, Cumhuriyet, Dicle, Karadeniz Teknik Üniversiteleri” gibi 1990 öncesinde kurulmuş üniversitelerde kamu yönetimi ve kamu yönetimi ve siyaset bilimi programları açılmıştır. Takiben 1992 yılında kurulan “Abant İzzet Baysal, Adnan Menderes, Afyon Kocatepe, Balıkesir, Çanakkale Onsekiz Mart Üniversiteleri” gibi 20 üniversitede kamu yönetimi bölümleri açılmıştır. Ardından 1994 yılında kurulan Galatasaray Üniversitesi’nde ve 2006 yılında kurulan “Adiyaman, Ahi Evran, Aksaray, Erzincan, Hitit ve Uşak Üniversiteleri'nde” kamu yönetimi bölümleri kurulmuştur. 2007 yılında kurulan "Bilecik, Bingöl, Karabül” gibi 9 üniversitede de kamu yönetimi bölümü bulunmaktadır. Ayrıca yine bu süreç içinde kurulmuş olan birçok vakıf üniversitesinde de kamu yönetimi bölümü bulunmaktadır. 
1990 sonrasındaki gelişim sürecini değerlendirmek için şöyle bir bilgiyi göz önünde bulundurabiliriz: Kaya (1995, s.254), 1992-93 öğretim yılında 36 üniversitede, İktisadi ve İdari Bilimler Fakültesi altında kamu yönetimi bölümünün bulunduğunu, ancak bunlardan 19 tanesinin henüz faaliyete geçmemiş olduğunu belirtmiştir. Bugün Yükseköğretim Veri Sistemi'ne göre ise mevcut üniversitelerde yer alan kamu yönetimi bölümü sayısı ise 100'den fazladır (https://istatistik.yok.gov.tr/).

\section{Araştırma: Türkiye'de Kamu Yönetimi Bölümlerinde İnsan Hakları Eğitimi}

Bu bölümde yer alan araştırma YÖK tarafından web sitesinde paylaşılan istatistiki bilgiler temel alınarak ve ilgili üniversitelerin veri tabanları incelenerek gerçekleştirilmiştir. Öncelikle 2018 yılının Temmuz ayında Yükseköğretim Bilgi Yönetim Sistemi kapsamında erişilen bilgilerle Türkiye'de yer alan üniversiteler içinden "kamu yönetimi”, "siyaset bilimi ve kamu yönetimi”, "uluslararası ilişkiler ve kamu yönetimi" ve "siyaset ve kamu yönetimi" gibi adında "kamu yönetimi” ifadesi geçen programlarının bulunduğu fakülteler ve üniversiteler belirlenmiştir (URL 2). Elde edilen verilerden hareketle üniversitelerin ilgili bölümlerinin öğretim programları incelenmiştir. Çalışmanın temel amacı; genel olarak insan hakları dersinin ve konuyla ilişkili derslerin öğretim programlarında yer alıp almadığını ve söz konusu derslerin zorunlu dersler arasında mı seçmeli dersler arasında mı yer aldığını genel olarak belirlemektedir. Bu nedenle çalışmanın Türkiye'de yer alan üniversitelerin ilgili bölümlerini insan hakları dersleri açısından değerlendirmek ve bu kapsamda istatistiki veriler ortaya koymak gibi bir iddiası yoktur. Araştırma ile elde edilen bulgular şöyledir:

Yükseköğretim Bilgi Sistemi üzerinden yapılan araştırmaya göre adında "kamu yönetimi" ifadesi bulunan 121 program olduğu bilgisine erişilmiştir. $\mathrm{Bu} 121$ programdan yirmi bir programa web üzerinden erişim sağlanamamıştır. Bunun dışında öğretim program bilgisine erişilen ilgili bölümlerden sadece sekiz tanesinde "İnsan Hakları" dersinin “zorunlu ders” olarak yer aldığg görülmüştür. "İnsan Hakları” dersinin "seçmeli” dersler arasında yer aldığı program sayısı ise on altı olarak belirlenmiştir. Konuya ilişkin bilgiler Tablo 1'de yer almaktadır. 
Tablo 1. "İnsan Hakları" Başlıklı Dersin "Zorunlu” ve "Seçmeli” Olduğu Programlara İlişkin Bilgiler *

\begin{tabular}{|c|c|}
\hline İnsan Hakları Dersi & Üniversite, Fakülte, Bölüm \\
\hline Zorunlu & $\begin{array}{l}\text { Afyon Kocatepe, İİBF, SBKY } \\
\text { İstanbul Arel, İİB, SBKY } \\
\text { İstanbul, SBF, SBKY } \\
\text { Kahramanmaraş Sütçü İmam, İİBF, KY } \\
\text { Karabük, İİBF, SBKY } \\
\text { Kastamonu, İIBF, SBKY } \\
\text { Muş Alparslan, İ̈BF, SBKY } \\
\text { Trakya, İ̈BF, KY }\end{array}$ \\
\hline Seçmeli & $\begin{array}{l}\text { Adana Bilim ve Teknoloji, SBF, SBKY } \\
\text { Ankara Yıldırım Beyazıt, SBF, SBKY } \\
\text { Bandırma Onyedi Eylül, İIBF, SBKY } \\
\text { Erzincan Binali Yıldırı,, İİB, SBKY } \\
\text { Eskişehir Osmangazi, İ̈BF, SBKY } \\
\text { Gaziantep, İİBF, SBKY } \\
\text { Hatay Mustafa Kemal, Islahiye İİBF, KY } \\
\text { Hitit, İ̇̈BF, SBKY } \\
\text { Iğdır, İİBF, SBKY } \\
\text { Kadir Has, İİBF, SBKY } \\
\text { Kafkas, İISBF, SBKY } \\
\text { Kırklareli, İ̈BF, SBKY } \\
\text { Mersin, İİBF, KY } \\
\text { Muğla Sıtkı Koçman, İİBF, KY } \\
\text { Necmettin Erbakan, İİBF, KY } \\
\text { Van Yüzüncü Yıl, İ̈BF, KY }\end{array}$ \\
\hline
\end{tabular}

Programlara yönelik gerçekleştirilen içerik analizinde ilgili bölümlerin bazılarında ders adı "insan hakları" olmayan ancak insan hakları konusuyla ilişkili derslerin olduğu görülmüştür. $\mathrm{Bu}$ derslerin isimleri ise; "İnsan Hakları Hukuku", "Temel Hak ve Özgürlükler/Hürriyetler” , "İnsan Hakları ve Demokrasi /Demokrasi ve İnsan Hakları /İnsan Hakları ve Demokrasi Kuramı", "İnsan Hakları, Demokrasi ve Sivil Toplum”, “İnsan Hakları Fikri”, "İnsan Hakları ve Özgürlükler”, "İnsan Hak ve Özgürlükleri”, “Avrupa İnsan Hakları Sistemi ve Türkiye”, "İnsan Haklarına Giriş”, "İnsan Hakları ve Güncel Sorunlar”, "Uluslararası Platformda İnsan Haklarının Korunması”, "Uluslararası İnsan Hakları Hukuku”, "Demokrasi Kalkınma ve İnsan Hakları”, “İnsan Hakları ve Uluslararası İlişkiler”, "İnsan Hakları ve Kamu Özgürlükleri”, “Kamu Hak ve Özgürlükleri”, “İnsan Hakları Araştırmaları I-II” olarak siralanabilir.

Öğretim programlarında bu isimlerle yer alan derslerin on altı tanesinin zorunlu dersler arasında, kırk bir tanesinin ise seçmeli dersler arasında yer aldığı belirlenmiştir. Konuya ilişkin, üniversite, fakülte, bölüm ve ders bilgileri Tablo 2'de mevcuttur. 
Tablo 2. "İnsan Hakları" Konulu "Zorunlu” ve "Seçmeli” Derslerin Bulunduğu Programlara İlişskin Bilgiler *

\begin{tabular}{|c|c|c|}
\hline $\begin{array}{l}\text { İnsan Hakları } \\
\text { konulu dersler }\end{array}$ & Üniversite, Fakülte ve Bölüm & Ders İsmi \\
\hline Zorunlu & 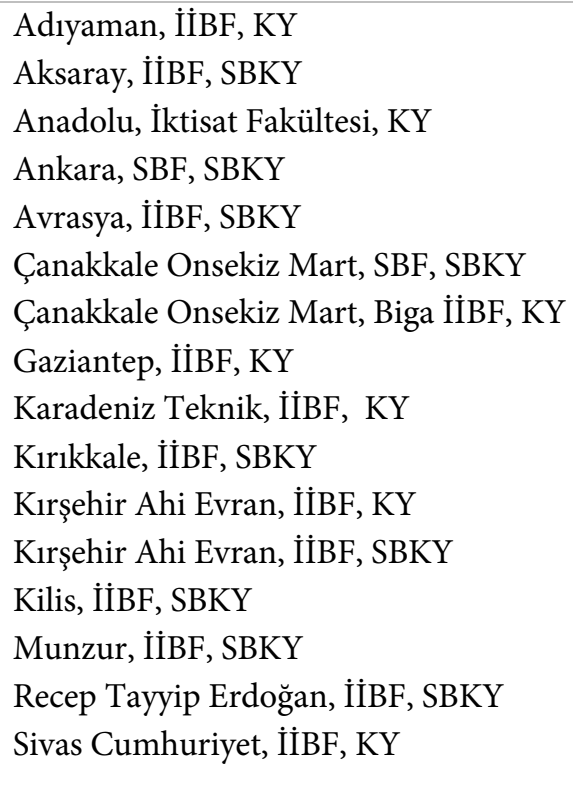 & $\begin{array}{l}\text { İnsan Hakları Hukuku } \\
\text { Demokrasi ve İnsan Hakları } \\
\text { İnsan Hakları ve Kamu Özgürlükleri } \\
\text { Temel Haklar ve Özgürlükler } \\
\text { İnsan Hakları Hukuku } \\
\text { İnsan Hakları ve Demokrasi } \\
\text { İnsan Hakları ve Demokrasi } \\
\text { Demokrasi ve İnsan Hakları } \\
\text { İnsan Hakları Hukuku } \\
\text { Temel Hak ve Özgürlükler } \\
\text { Temel Hak ve Hürriyetler } \\
\text { Temel Hak ve Hürriyetler } \\
\text { Demokrasi ve İnsan Hakları } \\
\text { İnsan Hakları Hukuku } \\
\text { İnsan Hakları, Demokrasi ve Sivil } \\
\text { Toplum } \\
\text { Temel Hak ve Özgürlükler }\end{array}$ \\
\hline Seçmeli & 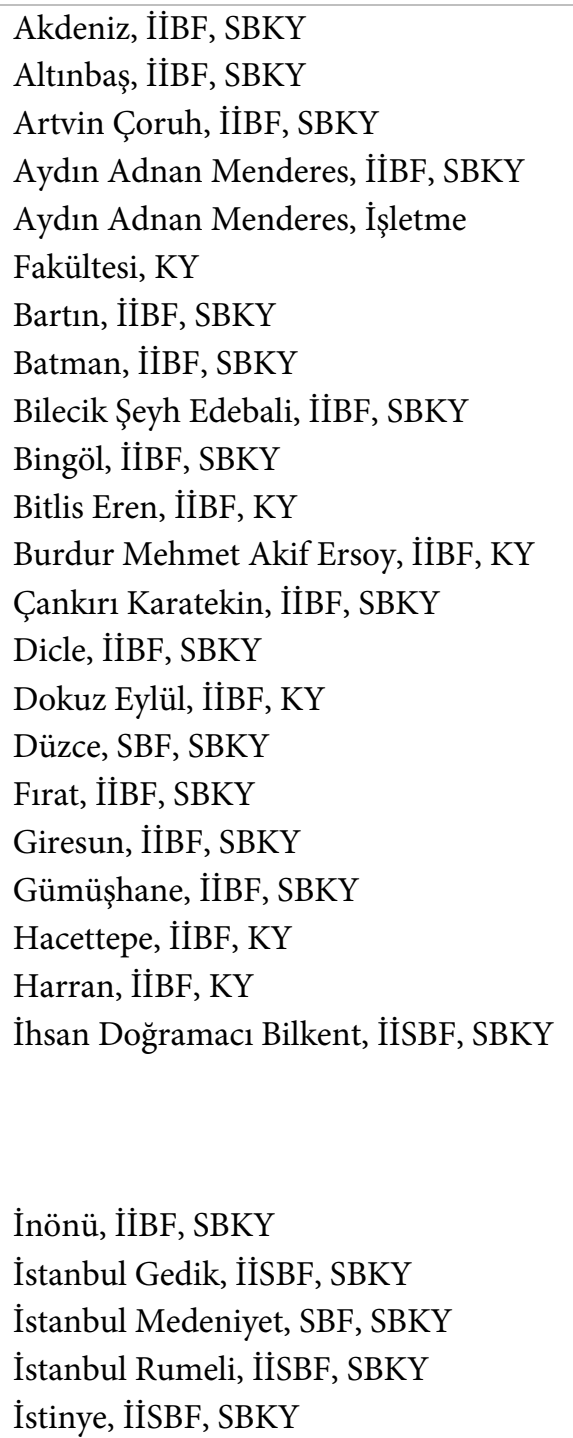 & $\begin{array}{l}\text { Temel Hak ve Özgürlükler } \\
\text { İnsan Hakları ve Uluslararası İlişkiler } \\
\text { İnsan Hakları ve Demokrasi } \\
\text { İnsan Hakları ve Demokrasi } \\
\text { İnsan Hakları ve Demokrasi } \\
\text { İnsan Hakları Hukuku } \\
\text { İnsan Hakları ve Demokrasi Kuramı } \\
\text { Kamu Hak ve Özgürlükleri } \\
\text { İnsan Hakları ve Demokrasi } \\
\text { Demokrasi ve İnsan Hakları } \\
\text { İnsan Hakları Hukuku } \\
\text { İnsan Hakları ve Demokrasi } \\
\text { İnsan Hakları ve Demokrasi } \\
\text { İnsan Hakları Hukuku } \\
\text { İnsan Hakları ve Demokrasi } \\
\text { İnsan Hakları Hukuku } \\
\text { İnsan Hakları ve Demokrasi } \\
\text { İnsan Hakları Hukuku } \\
\text { İnsan Hakları Hukuku } \\
\text { İnsan Hakları Hukuku } \\
\text { 1.Uluslararası Platformda İnsan } \\
\text { Haklarının Korunması } \\
\text { 2.Uluslararası İnsan Hakları Hukuku } \\
\text { 3.Demokrasi Kalkınma ve İnsan } \\
\text { Hakları } \\
\text { İnsan Hakları ve Demokrasi } \\
\text { İnsan Hakları Hukuku } \\
\text { Temel Hak ve Özgürlükler } \\
\text { İnsan Hakları ve Özgürlükler } \\
\text { İnsan Hakları ve Güncel Sorunlar }\end{array}$ \\
\hline
\end{tabular}




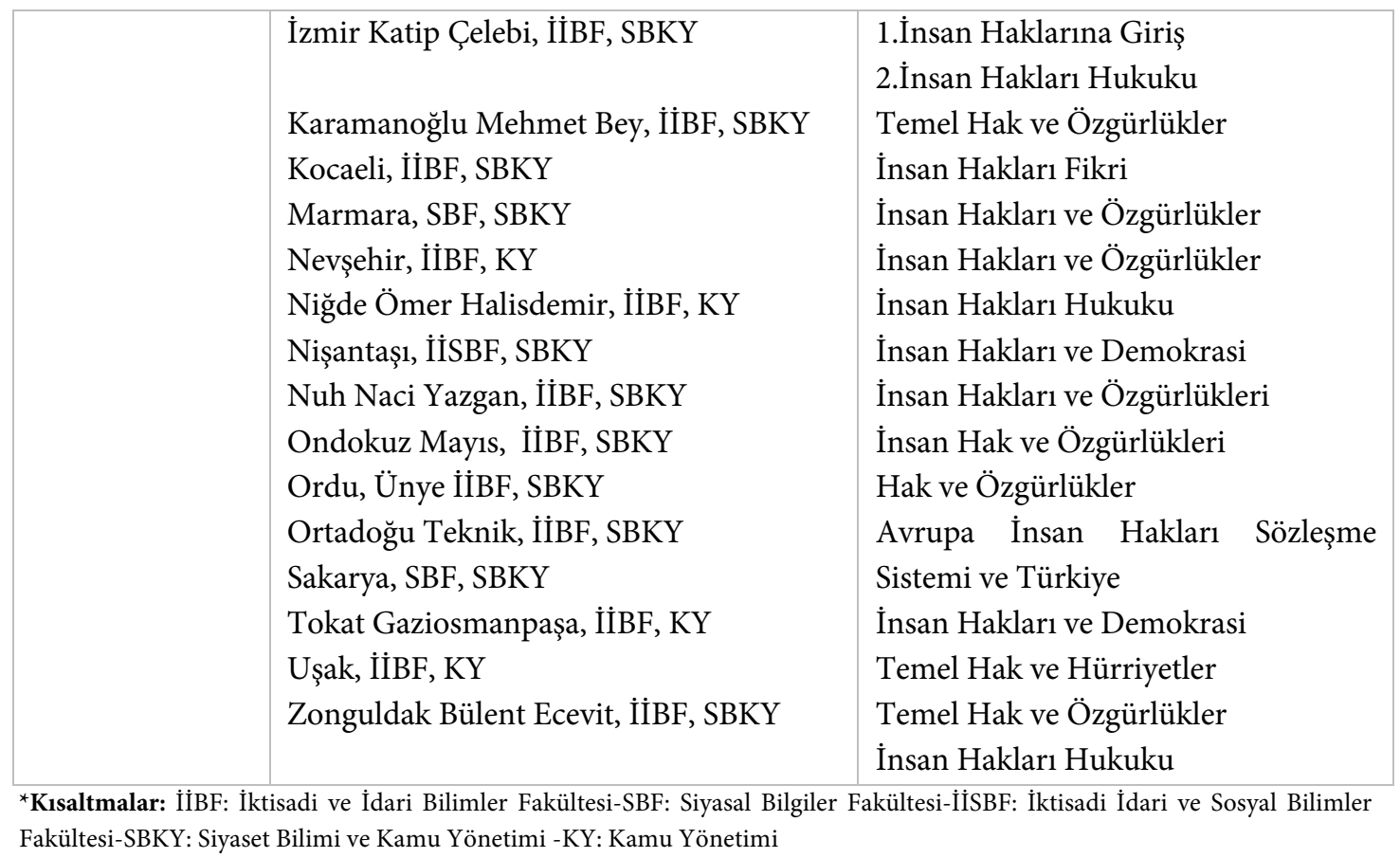

Yapılan araştırmada 20 öğretim programında ise "İnsan Hakları" veya insan hakları konusuyla ilişkili herhangi bir derse rastlanmamıştır.

Sonuç olarak, 2018 yılında Yükseköğretim Bilgi Yönetim Sistemi’nden alınan verilere göre yükseköğretimde adında "kamu yönetimi" geçen 122 lisans programı olduğu bilgisine erişilmiştir. $\mathrm{Bu}$ programlardan 101 tanesinin öğretim programlarına erişilebilmiştir. 101 programın 20'sinde insan hakları ve insan hakları konusuyla ilgili herhangi bir derse rastlanmamıştır. Bununla birlikte insan hakları ve insan hakları konusuyla ilgili zorunlu ders sayısı yirmi dört, seçmeli ders sayısı ise elli yedi olarak belirlenmiştir.

\section{Sonuç ve Değerlendirme}

İnsan hakları insanların doğuştan sahip oldukları vazgeçilmez, devredilmez ve bölünmez nitelikli haklardır. İnsan hakları "ortak insanlık dili” olarak tanımlanmaktadır (Boutros-Ghali, 1993, s.3). Buradan hareketle insan hakları eğitimi ise kişilere bu ortak dili öğretme eğitimi olarak anlaşılabilir. İnsan hakları herkesin sahip olduğu haklar olduğu için insan hakları eğitimi de herkes için gerekli bir eğitimdir ancak bazı meslekleri icra eden kişiler için insan hakları eğitimi özellikle önemlidir. Kamu görevlileri de bu kişiler arasında yer almaktadır. Bu konuda BM belgeleri de bu durumu desteklemektedir:

BM belgelerinde insan hakları eğitimi birkaç bölüm halinde ele alınmaktadır. Bunlar ilk ve ortaokullarda insan hakları eğitimi; yükseköğretimde insan hakları eğitimi; “öğretmenlerin, eğitimcilerin, kamu personelinin, kolluk kuvvetlerinin ve askeri personelin" insan hakları konusunda eğitimi ve "medya çalışanları ile gazetecilerin" insan hakları eğitimi olarak ayrılmaktadır. Yine bu konuda BM Genel Kurulu'nca ilan edilen “İnsan Hakları Eğitimi için Dünya Programı” çerçevesinde 2005-2009 dönemini oluşturan ilk aşamada insan hakları eğitiminin ilk ve orta öğretim düzeyinde öğretim programlarına dâhil edilmesi hedeflenmiştir. 
İkinci aşama olarak; 2010-2014 dönemi ise insan haklarının yüksek öğretime entegre edilmesini ve "öğretmenlerin, eğitimcilerin, kamu personelinin, kolluk kuvvetlerinin ve askeri personelinin" insan hakları konusunda eğitilmesini kapsayan bir dönem olarak tanımlanmıştır. 2015-2019 dönemini kapsayan üçüncü etabın hedefi ise; ilköğretim, ortaöğretim, yükseköğretimde insan hakları eğitiminin geliştirilmesi ve kamu personeli, kolluk gibi kamusal alanda hizmet veren grupların insan hakları eğitimi konusunda güçlendirilmesidir. Bunun yanında üçüncü dönemin bir başka hedefi de "medya çalışanları ile gazetecilerin" insan hakları konusunda eğitilmesidir.

Kişilerin önce ilköğretimde sonra ortaöğretimde ve sonrasında ise yükseköğretimde insan haklarını "hem kendilerinde hem de başkalarında" koruyacak şekilde bir insan hakları eğitimine tabi tutulmaları oldukça önemlidir. Zira geçmiş dönemlerde kişilerin sözü edilen eğitime erişememeleri bugün insan hakları eğitiminin eğitim kurumları dışına taşmasına neden olmuştur. Bu nedenledir ki, bugün insan hakları eğitimi hem sivil toplumda hem de kamusal alanda gerçekleşen ve devlet memurları, kolluk personeli, eğitimciler gibi insan haklarının korunması açısından önemli olduğu düşünülen gruplara odaklanan bir eğitim haline de gelmiştir.

Türkiye'de yükseköğretimde insan hakları eğitimi yeterli olmamakla birlikte önemli aşamalar kaydetmiştir. Örneğin, Türkiye'de insan hakları konusunda yüksek lisans eğitimi veren üniversiteler mevcuttur. Yine bazı üniversitelerde insan hakları konusuyla ilgili araştırma ve uygulama merkezleri bulunmaktadır. Ayrıca insan hakları konulu bazı dersler bir takım fakültelerde "seçmeli" dersler arasında yer almaktadır. "Kamu yönetimi" bölümleri özelinde insan hakları eğitimine baktığımızda da çalışma kapsamında erişilen bulgulara göre kamu yönetimi eğitiminde insan hakları dersleri zorunlu ya da seçmeli olarak öğretim programlarının büyük kısmında yer almaktadır. Ancak erişilen programların (yaklaşık olarak) sadece dörtte birinde insan hakları ve insan hakları konusuyla ilgili dersler zorunlu dersler arasinda yer almaktadır. Programların yarısından fazlasında ise ilgili derslerin "seçmeli" dersler arasında yer aldığı görülmüştür. Bazı öğretim programlarında ise konuya ilişkin herhangi bir derse rastlanmamıştır. Diğer bir taraftan, insan hakları dersinin öğretim programında var olmasının da yeterli olmadığını belirtmek gerekmektedir. Zira dersin varlığı kadar önemli bir diğer konu da dersin içeriğidir. Ancak bu konu farklı bir araştırma konusu olduğu için bu çalışmada ele alınmamıştır.

“İnsan Hakları Eğitimi için Dünya Programı” kapsamında BM İnsan Hakları Yüksek Komiserliği (United Nations Human Rights Office of the High Commissioner - OCHRC) tarafından taraf devletlerin ulusal raporları temel alınarak hazırlanan gelişme raporuna baktığımızda ise yükseköğretimde insan hakları konusunda ülkeler arasında herhangi bir standart olmadığını belirtebiliriz (UN, 2017, s.8). Raporda yer alan bilgiler çerçevesinde yükseköğretimde insan hakları dersinin zorunlu ders olarak öğretim programlarında yer alması konusunda herhangi bir bilgiye rastlanmamıştır. Ülkelerden "ulusal düzeyde" gelen bilgiler çerçevesinde oluşturulan raporda insan hakları alanında lisans düzeyinde verilen insan hakları dersi sayısı da oldukça kısıtlıdır. Bu yetersiz durum lisansüstü eğitim ve konuya ilişkin araştırma merkezleri konusunda da benzerdir. Örneğin, Azerbaycan'da "insan hakları" ve "toplumsal cinsiyet” konularıyla ilgili üniversite düzeyinde derslerin bulunduğundan, 2015 yllında 
Meksika'da bazı üniversitelerde insan hakları konusunun eğitim programlarına dâhil edildiğinden söz edilmiştir (UN, 2017, s.8). Ayrıca, Rusya Federasyonu'nda yükseköğretim kurumları ile OCHRC işbirliği ile insan hakları programı hayata geçirildiğinden ve 2016 yılında Uruguay Cumhuriyet Üniversitesi'nde insan hakları ile ilgili yeni bir akademik birim oluşturulduğundan söz edilmiştir (UN, 2017, s.8). Arjantin'de ise lisans ve lisansüstü düzeyde insan hakları eğitimi veren çeşitli üniversitelerin varlı̆̆ından söz edilmiş ve bu konuya örnek olarak; Buenos Aires Üniversitesi Hukuk Fakültesi'de yer alan insan hakları merkezi ve Lanus Ulusal Üniversitesi’nde tüm öğrenciler için zorunlu tutulan adalet ve insan hakları dersi sıralanmıştır. "Kore Ulusal İnsan Hakları Komitesi”nin oniki üniversitede insan hakları eğitimi konusunda araştırma merkezi oluşturulması sürecini başlattığı da yine raporda belirtilen bir diğer gelişmedir.

Bu örneklerin dışında Slovenya tarafından İnsan Hakları Yüksek Komiserliğine iletilen ulusal raporda Ljubljana Üniversitesi'nde insan hakları konularının ve insan haklarıyla ilgili sorunların hukuk fakültelerinde yer alan derslerin bir parçası olarak ele alındığı ve fakültede “Avrupa İnsan Hakları Hukuku” adlı bir ders bulunduğu belirtilmiştir. Hukuk fakültesinde doktora düzeyinde ise insan haklarının korunması hakkında derslerin öğretim programında yer aldığı aktarılmıştır. Üniversite'nin Sosyal Bilimler Fakültesinde ise "insan haklarının uluslararası alanda korunması", "azınlıkların uluslararası korunması" ve "Avrupa'da insan haklarının korunması” gibi derslerin olduğu belirtilmiştir. Yine raporda fakülte bünyesinde "İnsan Hakları ve Demokratikleşme" alanında yüksek lisans programı olduğu da ifade edilmiştir. Üniversitenin Sosyal Hizmet Fakültesi'nde de insan hakları konularıyla ilgili derslerin bulunduğu rapora eklenmiştir (Slovenia Midterm Progress Report, 2017, s.3). Almanya tarafindan iletilen rapor lisansüstü programlar ve insan hakları alanında çalışan kurumlar bakımından oldukça zengindir. Raporda insan hakları konusunun hukuk, sosyal bilimler, felsefe ve teoloji, sağlık bilimleri ve eğitim bilimleri gibi alanlarda ele alındığ belirtilmiştir. Ayrıca raporda, Friedrich-Alexander Üniversitesi'nde ve Eberhard Karls Üniversitesi'nde "insan hakları eğitimi” alanında çalışan birimlerin olduğundan ve yine farklı üniversitelerde "uluslararası insan hakları", "insancıl hukuk", "soykırım çalışmaları”, "barış ve çatışma araştırmaları" gibi "insan hakları mesleği” ile ilgili yüksek lisans programlarının bulunduğundan söz edilmiştir. Yine, insan hakları konularının ele alındığı enstitülerin de olduğu belirtilmiştir. Bu enstitülere örnek olarak "Avrupa Hukuk ve Politika Merkezi”, "Saarland Üniversitesi İnsan Hakları Enstitüsü”, "Uluslararası Savaş Suçları Davaları Araştırma ve Belgelendirme Merkezi”, "Çatışma Araştırmaları Merkezi” sıralanmıştır (Statement of the German Government, 2017). Raporlarda ve yapılan literatür çalışmasında insan hakları derslerinin bölüm bazında öğretim programlarında ne şekilde yer aldığı hakkında herhangi bir bilgiye erişilememiştir.

Bu bilgiler yükseköğretimde "insan hakları" eğitiminde herhangi bir standardın olmadığını göstermektedir. Ancak konuya ilişkin önemli düzenlemelerin ve gelişmelerin varlığı da göz ardı edilmemelidir. Sonraki çalışmalarda yükseköğretimde insan hakları eğitiminin içeriği üzerine bir araştırma gerçekleştirilerek literatüre katkı sağlanabilir. 


\section{Kaynakça}

Altan, Y. , Kerman, U. ve Aktel M. (2009). Kamu Yönetiminde Lisans Öğretimi: Kamu Yönetimi Öğrencileri Üzerinde Bir Araştırma. SDÜ Fen Edebiyat Fakültesi Sosyal Bilimler Dergisi, Aralık(20), 227-252.

Boutros-Gali, B. (1993). World Conference on Human Rights. https://documents-ddsny.un.org/doc/UNDOC/GEN/G93/142/39/PDF/G9314239.pdf?OpenElement

Council of Europe (1985). Recommendation No. R (85) 7 of the Committee of Ministers to Member States on Teaching and Learning About Human Rights in Schools. https://rm.coe.int/16804c2d48

Çiner, C. U. (2015). Kamu Yönetimi Eğitimi ve Öğretimi Literatürü Üzerine Bir Çözümleme. Murat Okcu, Bekir Parlak ve Elvettin Akman (Ed.), Kamu Yönetimi Eğitimi Geçmişten Geleceğe Küresel ve Ulusal Perspektifler içinde (s.3-25). Bursa: Ekin.

Eryılmaz, B. (2016). Kamu Yönetimi. Kocaeli: Umuttepe.

Flowers, N., Bernbaum, M., Rudelius-Palmer, K., Tolman, J. (2000). The Human Rights Education Handbook. Minnesota: University of Minnesota.

Statement of the German Government: OHCHR Midterm Progress Report on the Implementation of the Third Phase of the World Programme For Human Rights Education, As Requested By HRC Resolution 27/12. https://www.ohchr.org/Documents/Issues/Education/Training/thirdphase/ ProgressReport/Governments/Germany_3rdphasemidterm_2017.pdf

Gül, H., Okçu, M., Akman Ç., Akman E., Negiz N. \& Kiriş, M. (2017). Nasıl Bir Kamu Yönetimi Eğitimi? Kamu Yönetimi Eğitimi Çalıştayı Çıktılarının Bir Değerlendirmesi. Yüzüncü Yıl Üniversitesi Sosyal Bilimler Enstitüsü Dergisi, 1(Özel Sayı 4). http://www.yyusbedergisi.com/dergi/nasil-birkamu-yonetimi-egitimi-kamu-yonetimi-egitimi-calistayi-ciktilarinin-birdegerlendirmesi2017 1230032914.pdf

Gülmez, M. (1996). Türkiye'de İnsan Hakları Çalışmalarına Toplu Bir Bakış. İnsan Hakları Yıllığı 17 18/1, 221-246.

İnsan Hakları Evrensel Bildirisi, 1948. http://www.unicankara.org.tr/doc_pdf/h_rigths_turkce.pdf

Kaya, Y. K. (1995). Türkiye’de Kamu Yönetimi Öğretimi. Kamu Yönetimi Disiplini Sempozyumu Bildirileri Cilt II içinde (249-269). Ankara: TODAİE.

Lohrenscheit, C. (2002). International Approaches in Human Rights Education. International Review of Education, 48(3-4), 173-185.

Kuçuradi, İ. (2004a). İnsan Hakları Kavramları ve Sorunları. Ankara: Türkiye Felsefe Kurumu.

Kuçuradi, İ. (2004b). İnsan Hakları Eğitimi ve Dayanışma İçin Eğitim: Eğiticilerin Eğitimi. İoanna Kuçuradi, Bülent Peker (Ed.), Elli Yıllık Deneyimlerin Işı̆̆ında Dünyada ve Türkiye'de İnsan Hakları içinde (375-381). Ankara: Türkiye Felsefe Kurumu.

Milli Eğitim Bakanlığı (2018a). İnsan Hakları, Demokrasi ve Yurttaşlık Dersi Öğretim Programı. http://mufredat.meb.gov.tr/Dosyalar/2018120202622474INSAN\%20HAKLARI\%20YURTTASL IK\%20VE\%20DEMOKRASI\%20OGRETIM\%20PROGRAMI.pdf

Milli Eğitim Bakanlığı, (2018b), Ortaöğretim Kurumları Haftalık Ders Çizelgeleri-2018 https://ttkb.meb.gov.tr/meb_iys_dosyalar/2018_02/21173451_ort_ogrtm_hdc_2018.pdf

Milli Eğitim Bakanlığı (1995). Tebliğler Dergisi, 1995-2437, file:///C:/Users/user/Downloads/2437agustos-1995.pdf

Milli Eğitim Bakanlığı (1996). Tebliğler Dergisi, Temmuz-2457, file:///C:/Users/user/Downloads/2457temmuz1996.pdf 
Milli Eğitim Bakanlığı (1999). Tebliğler Dergisi, 1999-2501, file:///C:/Users/user/Downloads/2501haziran_1999.pdf

Ömürgönülşen, U. (2010). Türkiye’de Lisans Düzeyi Kamu Öğretiminde Yakın Dönemde Yaşanan Gelişmeler: Mevcut Durum, Sorun Alanları ve Gelişme Eğilimleri. Ankara Üniversitesi SBF Dergisi, 65(3), 123-162.

Parlak, B. (2015). Kamu Yönetimi Eğitiminin Tarihsel Kökenleri. Murat Okcu, Bekir Parlak ve Elvettin Akman (Ed.), Kamu Yönetimi Eğitimi Geçmişten Geleceğe Küresel ve Ulusal Perspektifler içinde (s.53-77). Bursa: Ekin Yayınları.

Reardon, A. B. (1995). Educating for Human Dignity: Learning About Human Rights and Responsibilities. Philedelphia: University of Pennsylvania Press.

Selvi, K. (2004). Human Rights Education in the World and in Turkey. Education and Science, 29(132), 72-77.

Slovenia: Midterm 2017 Progress Report on the Implementation of the Third Phase of the World Programme For Human Rights Education, https://www.ohchr.org/Documents/Issues/ Education/Training/thirdphase/ProgressReport/Governments/Slovenia_3rdphasemidterm_201 7.pdf

UN, (2017). Midterm progress report on the implementation of the third phase of the World Programme for Human Rights Education. Repert of the Office of the United Nations High Commissioner for Human Rights. https://documents-dds-ny.un.org/doc/ UNDOC/GEN/G17/178/13/PDF/G1717813.pdf?OpenElement

UNESCO, (1974). Recommendation Concerning Education For International Understanding, Cooperation and Peace and Education Realating to Human Rights and Fundamental Freedoms. http://portal.unesco.org/en/ev.phpURL_ID=13088\&URL_DO=DO_TOPIC\&URL_SECTION= 201.html

UNESCO, (1978). The Teaching of Human Rights - Proceedings of the International Congress on the Teaching of Human Rights Vienna, 12-16 September 1978. http://unesdoc.unesco.org/ images/0004/000401/040182eo.pdf

UNESCO, (1987). Report by the Director-General on the Proceedings of the International Congress on Human Rights Teaching, Information and Documentation. http://unesdoc.unesco.org/images/ 0007/000762/076217eo.pdf

UNESCO. (1993). Human Rights Teaching, International Congress on Education for Human Rights and Democracy, http://unesdoc.unesco.org/images/0016/001610/161096eo.pdf

UNESCO, (2017). World Programme For Human Rights Education. https://www.ohchr.org/ Documents/Publications/ThirdPhaseWPHREducation.pdf

URL 1: Yükseköğretim Kurulu, https://www.yok.gov.tr/kurumsal/tarihce

URL 2: Yükseköğretim Bilgi Yönetim Sistemi. https://istatistik.yok.gov.tr/ 